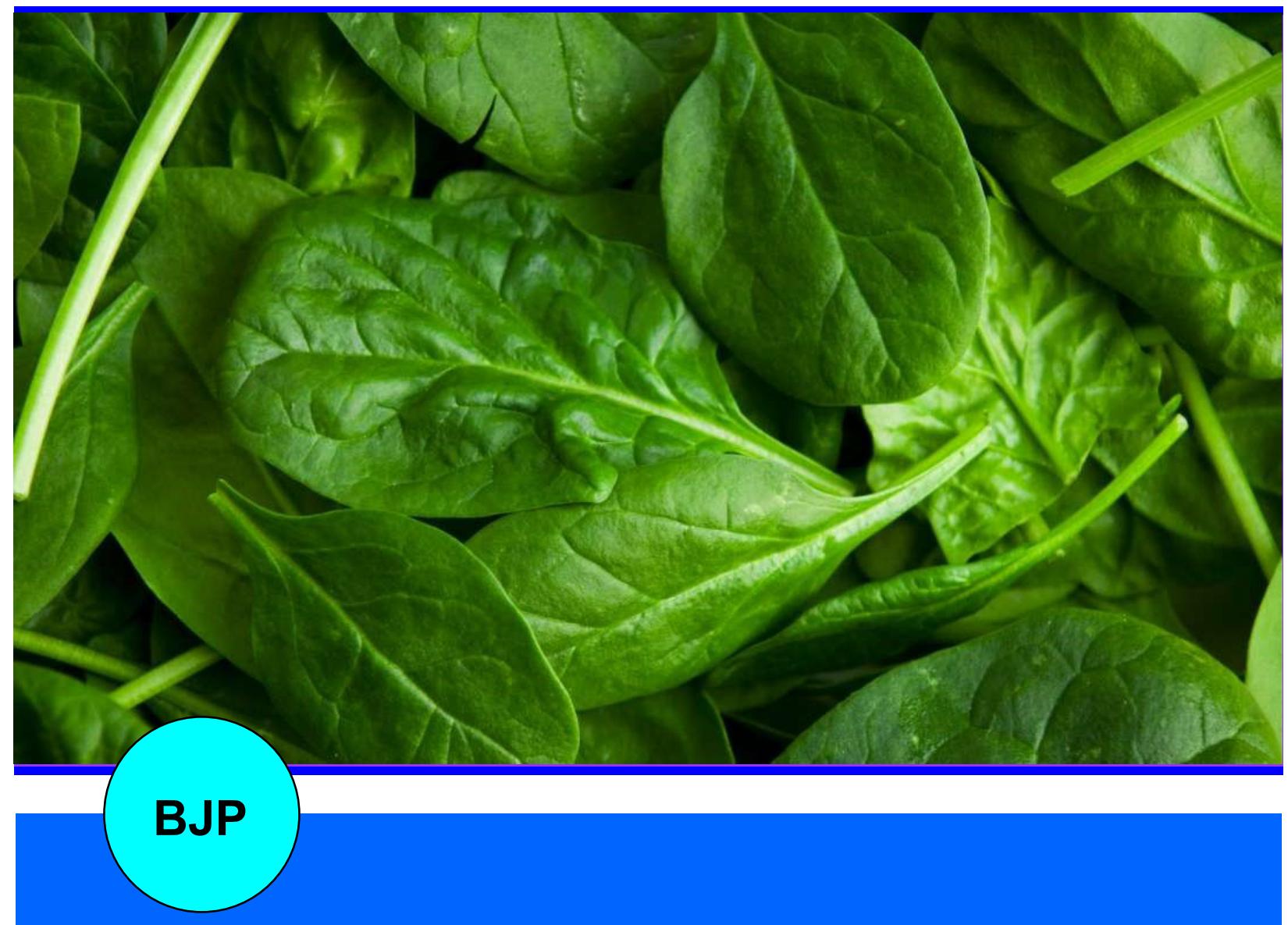

Bangladesh Journal of Pharmacology

Research Article

Effect of hexane extract of spinach in the removal of arsenic from rat 
Abstracted/indexed in Academic Search Complete, Asia Journals Online, Bangladesh Journals Online, Biological Abstracts, BIOSIS Previews, CAB Abstracts, Current Abstracts, Directory of Open Access Journals, EMBASE/Excerpta Medica, Global Health, Google Scholar, HINARI (WHO), International Pharmaceutical Abstracts, Open J-gate, Science Citation Index Expanded, SCOPUS and Social Sciences Citation Index;

ISSN: $1991-0088$

\section{Effect of hexane extract of spinach in the removal of arsenic from rat}

\section{Badar Uddin Umar}

Department of Pharmacology, Bangabandhu Sheikh Mujib Medical University, Shahbag, Dhaka 1000, Bangladesh.

\begin{tabular}{|c|c|}
\hline \multicolumn{2}{|l|}{ Article Info } \\
\hline Received: & 4 March 2007 \\
\hline Accepted: & 6 May 2007 \\
\hline Available Online: & 3 January 2008 \\
\hline \multicolumn{2}{|c|}{ DOI: 10.3329/bjp.v2i1.497 } \\
\hline \multicolumn{2}{|c|}{$\begin{array}{l}\text { Cite this article: } \\
\text { Umar BU. Effect of hexane extract of } \\
\text { spinach in the removal of arsenic } \\
\text { from rat. Bangladesh J Pharmacol. } \\
2007 ; 2: 27-34 \text {. }\end{array}$} \\
\hline
\end{tabular}

\begin{abstract}
Extensive search is going on for a cheap, easily available and effective remedy of chronic arsenic poisoning. The present study was designed to find the effects of hexane extract of spinach in the removal of arsenic from arsenic treated rat. Rats were fed arsenic trioxide through Ryle's tube for one month then they were fed on hexane extract $(1-4 \%)$ of spinach for another one month. Hexane extract of spinach decreased accumulated arsenic from rat liver, spleen, kidney, intestine, lungs and skin significantly. Besides, it reduced the oxidative stress caused by arsenic which was evident by decreased levels of malondialdehyde (MDA) in the above tissues. Hexane extract decreases both arsenic level and MDA level in rat tissues in dose dependent manner, which is more effective at lower doses.
\end{abstract}

\section{Introduction}

Chronic arsenic toxicity is a global health issue at present (Yoshida et al., 2004). It is also a major health problem of Bangladesh and surrounding regions (Guha Mazumder et al., 2001; Kalia and Flora, 2005; Khalequzzaman et al., 2005). There is no specific curative treatment. Immediate stoppage of drinking arsenic contaminated water and consumption of arsenic free drinking water are the mainstay of therapy (Dey, 2002). Improvement of nutritional status (Mitra et al., 2004; Milton et al., 2004) and use of chelating agents are recommended (Kalia and Flora, 2005). But the role of chelating agents in chronic arsenic poisoning is not beyond doubt (Guha Mazumder et al., 1998). Clinical trials in West Bengal of India arsenic chelators such as BAL, $d$-penicillamine, DMSA and DMPS have not shown promising results (Rahman et al., 2001). Vitamin A, E, C regimen with arsenic free water was proved to be effective in improving arsenic-induced melanosis and keratosis (Ahmad et al., 1998). Spirulina extract plus zinc was found to be beneficial in patients of chronic arsenic poisoning (Misbahuddin et al., 2006). Over production of free radicals leading to oxidative stress has been postulated as one of the major mechanism behind arsenic induced toxicities in different organs (Kokilavani et al., 2005; Ramos et al., 1995). In view of anti-oxidant properties of spinach the present study was carried out to document the effectiveness of spinach extract against chronic arsenic toxicity.

\section{Materials and Methods}

\section{Chemicals and reagents}

Arsenic trioxide $\left(\mathrm{As}_{2} \mathrm{O}_{3}\right)$, silver diethyldithiocarbamate (SDDC), hexamethylenetetramine, zinc fillings and other reagents for arsenic estimation were purchased from E. Merck (Germany). Thiobarbituric acid and 


\begin{tabular}{|c|c|c|c|}
\hline \multicolumn{4}{|c|}{ Table I } \\
\hline \multicolumn{4}{|c|}{ Experimental design } \\
\hline \multirow[t]{2}{*}{ Groups } & \multirow[t]{2}{*}{$\mathrm{n}$} & \multicolumn{2}{|c|}{ Feeding schedule } \\
\hline & & 1st month & 2nd month \\
\hline 0 & 6 & Food and water only & Food and water only \\
\hline I & 11 & Arsenic $(0.7 \mathrm{~mL})+$ food and water & Food and water only \\
\hline II & 11 & Arsenic $(0.7 \mathrm{~mL})+$ food and water & $1 \%$ spinach extract + food and water \\
\hline III & 11 & Arsenic $(0.7 \mathrm{~mL})+$ food and water & $2 \%$ spinach extract + food and water \\
\hline IV & 11 & Arsenic $(0.7 \mathrm{~mL})+$ food and water & $3 \%$ spinach extract + food and water \\
\hline $\mathrm{V}$ & 11 & Arsenic $(0.7 \mathrm{~mL})+$ food and water & $4 \%$ spinach extract + food and water \\
\hline
\end{tabular}

bovine serum albumin were purchased from SigmaAldrich Cheme (Gmbh, Germany). All the chemicals and reagents used were of highest analytical grade available.

\section{Procedure for obtaining dried leaves of spinach}

Seventy two kilograms of spinach (Spinacia oleracea) was purchased from the local market. Then they were cleaned, washed and chopped excluding the roots. Then they were dried in the open air at room temperature for 2-3 days without exposure to direct sunlight. After drying the crisp leaves were crushed by hand.

\section{Procedure for obtaining n-hexane extract of spinach}

The dried leaves of the spinach after crushing was soaked in $n$-hexane in clean amber colored glass containers for 24 hours. After 24 hours they were filtered. The filtrate thus obtained was condensed by rotatory vacuum evaporator at $40^{\circ} \mathrm{C}$ temperature and 65-75 revolution per $\mathrm{min}$. The yellowish-green oily extract was preserved in amber colored bottle in the deep freezer.

\section{Procedure for preparation of spinach extract in olive oil}

$1,2,3$ and $4 \%$ solutions of $n$-hexane extract of spinach in olive oil were prepared by dissolving 1, 2, 3 and $4 \mathrm{~mL}$ of spinach extract concentrate in 99, 98, 97 and $96 \mathrm{~mL}$ of olive oil and preserved in amber color bottles and kept in the refrigerator.

\section{Research design}

Rats were randomly divided into five groups $(0-\mathrm{V})$ (Table I). Group 0 rats received only food and water ad libitum for the whole study period and were considered as healthy control group. All the rats of Group I-V received $0.7 \mathrm{~mL}$ of arsenic solution (from $2 \mathrm{mg} / \mathrm{mL}$ stock solution) through Ryle's tube on every alternate day for 30 days. Then on next 30 days- all the rats of Group I was fed normal diet and drinking water ad libitum and was considered as arsenic control group. Group II rats received $0.5 \mathrm{~mL}$ of $1 \% n$-hexane extract of spinach in olive oil by Ryle's tube besides normal diet and water ad libitum every day. In addition to normal diet and drinking water ad libitum all the rats of Group III received $0.5 \mathrm{~mL}$ of $2 \% n$-hexane extract of spinach in olive oil by Ryle's tube every day. In addition to normal diet and drinking water ad libitum all the rats of Group IV received $0.5 \mathrm{~mL}$ of $3 \% n$-hexane extract of spinach in olive oil by Ryle's tube every day. All the rats of Group $\mathrm{V}$ received $0.5 \mathrm{~mL}$ of $4 \% n$-hexane extract of spinach in olive oil by Ryle's tube every day in addition to normal diet and drinking water ad libitum.

\section{Sacrifice of animals and collection and preservation of organs}

All the rats were sacrificed at the end of 60 days. Sacrifice procedure was performed under light chloroform anesthesia. Rats were kept fasting overnight the day before sacrifice. Under light chloroform anesthesia the abdomen of each rat was opened by midline incision and extended to open the thorax. Then the liver, spleen, kidneys, intestine, lungs and skin were isolated. The organs were dissected out and packed in separate polyethylene packets accurately labeled and preserved in a deep freezer until the period of analysis.

\section{Estimation of tissue arsenic level}

The amount of total arsenic in tissues was measured by quantitative colorimetric method for total arsenic estimation using SDDC method. Inorganic arsenic was reduced to arsine $\left(\mathrm{AsH}_{3}\right)$ by zinc in strong acid solution 
in an arsine generator. The arsine was then passed through a scrubber containing cotton wool moistened with lead acetate and into an absorber tube containing SDDC dissolved in chloroform. The arsine reacted with the silver salt, forming a soluble red color complex whose absorbance was read in a spectrophotometer. The maximum absorbance of the resulting color complex is at $525 \mathrm{~nm}$. From the particular organ specific amount of tissue was carefully weighed. Then arsenic in tissue was oxidized by "acid digestion" and released by "arsine generator".

\section{Acid digestion}

At first, the weighed tissue was taken in a $100 \mathrm{~mL}$ conical flask. Then $2 \mathrm{~mL}$ concentrated sulfuric acid, 3 $\mathrm{mL}$ concentrated nitric acid and $2 \mathrm{~mL}$ concentrated perchloric acid was added to it. To another $100 \mathrm{~mL}$ flask $25 \mathrm{~mL}$ of deionized distilled water was taken and above mentioned volume of sulfuric acid, nitric acid and perchloric acid was added. Then it was carried through entire procedure to use as blank, as acid contain trace amount of arsenic. The flasks were allowed to stand for $10 \mathrm{~min}$ then gentle heat was applied on the digestion plant. As the reaction subsided the heat was increased and kept on the flame till the contents of the flask became clear or colorless. Then the flame was turned off and the flasks were allowed to cool. When the digestion was completed all the carbonaceous material should have been destroyed, resulting in a solution of heavy metals in acid.

\section{Arsine generation}

After cooling the flasks, the digest contents were transferred to the clean and dry $250 \mathrm{~mL}$ conical flasks. Then the contents were diluted with deionized distilled water up to the volume of $35 \mathrm{~mL}$. To another flask 75 $\mu \mathrm{L}$ of prepared arsenic solution (containing $200 \mu \mathrm{g} / \mathrm{mL}$ ) was taken which contains $15 \mu \mathrm{g}$ of arsenic. It was diluted up to the volume of $35 \mathrm{~mL}$ by adding deionized distilled water. This was considered as standard for the study. To each flask $3 \mathrm{~mL}$ of concentrated hydrochloric acid and $50 \mu \mathrm{L}$ potassium iodide was added. Then after some time $100-200 \mu \mathrm{L}$ stannous chloride was added to each flask drop by drop till the contents of the flask became clear. Plugs of cotton wool wetted with a few drops of $10 \%$ lead acetate were inserted and placed in the scrubber part of the arsine generator assembly. 3 $\mathrm{mL}$ of SDDC was taken in each absorber part of arsine generator and $3 \mathrm{gm}$ zinc pellets were added to each flask. Then, immediately absorber part was joined tightly to generator part. Within minutes, reaction begun and bubbling was observed as arsine gas was generated. The reaction was allowed to continue for 30 min. For blank, the same procedure was carried on. After $30 \mathrm{~min}$ the color reagent or SDDC was transferred in a clean test tube and kept for colorimetric measurement of arsenic. Then, the color reagent was transferred to a glass cuvette and the absorbance was measured at $525 \mathrm{~nm}$ in spectrophotometer against blank.

\section{Lipid peroxidation assay}

Lipid peroxidation was estimated by using the thiobarbituric acid method to determine the level of malondialdehyde (MDA) (Hagen et al., 1999). One milliliter of tissue homogenate was reacted with $4.5 \mathrm{~mL}$ of $5.5 \%$ trichloroacetic acid (TCA). The mixture was vortexed and centrifuged at 4,000 rpm for $10 \mathrm{~min}$. To the supernatant $1 \mathrm{~mL}$ of $0.7 \%$ thiobarbituric acid was added. The mixture was kept in a boiling water bath $\left(100^{\circ} \mathrm{C}\right)$ for $10 \mathrm{~min}$, forming a pink color solution. It was then cooled immediately and then absorbance was measured at $532 \mathrm{~nm}$ by spectrophotometer. The results were expressed as nmol MDA/mg protein.

\section{Estimation of total protein}

Protein concentration of tissues was estimated by Lowry et al., 1951. Bovine serum albumin (8 g/dL) was used as standard.

\section{Statistical analysis}

Statistical Package for Social Science (SPSS), version 10.0 USA was used for data analysis and preparation of graphs. The values were expressed as mean $\pm \mathrm{SE}$. for results obtained with all six sets of tissues in all the five groups and significance of difference between the values was determined by unpaired students t-test. Statistical significance was determined by $p$ value $<0.05$.

\section{Results}

The concentration of arsenic in liver, spleen, kidneys, intestine, lungs and skin were estimated both in the presence or absence of arsenic and hexane extract of spinach.

The amount of arsenic (mean \pm SE) in the liver of normal healthy rats (Group 0) was $2.0( \pm 0.5) \mu \mathrm{g} / \mathrm{g}$ tissue. Rats treated with arsenic (Group I) for one 


\begin{tabular}{|c|c|c|}
\hline \multicolumn{3}{|c|}{ Table II } \\
\hline \multicolumn{3}{|c|}{ Arsenic level in rat liver } \\
\hline Groups & Concentration of arsenic in $\mu \mathrm{g} / \mathrm{g}$ tissue (mean $\pm \mathrm{SE}$ ) & $\%$ Decreased/Increased \\
\hline 0 & $2.0 \pm 0.5$ & - \\
\hline I: Arsenic control & $4.6 \pm 0.4$ & $\uparrow 126.5^{\mathrm{a}}$ \\
\hline II: $1 \%$ Spinach extract & $1.1 \pm 0.3$ & $\downarrow 76.6^{\mathrm{b}}$ \\
\hline III: $2 \%$ Spinach extract & $1.5 \pm 0.3$ & $\downarrow 68.6^{\mathrm{b}}$ \\
\hline IV: 3\% Spinach extract & $1.5 \pm 0.3$ & $\downarrow 67.5^{\mathrm{b}}$ \\
\hline V: $4 \%$ Spinach extract & $1.4 \pm 0.2$ & $\downarrow 69.9 \mathrm{~b}$ \\
\hline
\end{tabular}

${ }^{\mathrm{a} p}<0.01 ;{ }^{\mathrm{b}} \mathrm{p}<0.001$

Table III

Removal of arsenic from arsenic loaded tissues

\begin{tabular}{lccccc}
\hline Groups & \multicolumn{5}{c}{ \%Removal of arsenic from tissues } \\
\cline { 2 - 6 } & Spleen & Kidneys & Intestine & Lungs & Skin \\
\hline Arsenic control & - & - & - & - & - \\
$1 \%$ Spinach extract & $\downarrow 42.5$ & $\downarrow 44.2$ & $\downarrow 57.8$ & $\downarrow 56.06$ & $\downarrow 63.7$ \\
$2 \%$ Spinach extract & $\downarrow 63.4$ & $\downarrow 45.0$ & $\downarrow 48.0$ & $\downarrow 48.0$ & $\downarrow 48.6$ \\
$3 \%$ Spinach extract & $\downarrow 47.6$ & $\downarrow 54.7$ & $\downarrow 58.9$ & $\downarrow 45.8$ & $\downarrow 64.1$ \\
$4 \%$ Spinach extract & $\downarrow 45.0$ & $\downarrow 35.7$ & $\downarrow 53.9$ & $\downarrow 58.1$ & $\downarrow 51.9$ \\
\hline
\end{tabular}

Table IV

Malondialdehye level in different tissues

\begin{tabular}{|lrrrrrr|}
\hline & \multicolumn{5}{c}{ Malondialdehye level } \\
\cline { 2 - 7 } & \multicolumn{1}{c}{ Liver } & Spleen & Kidneys & Intestine & Lungs & Skin \\
\hline I: Arsenic control & $40.7 \pm 2.0$ & $152.4 \pm 2.7$ & $279.1 \pm 9.3$ & $363.3 \pm 27.9$ & $54.3 \pm 7.3$ & $18.3 \pm 1.3$ \\
II: $1 \%$ Spinach extract & $19.3 \pm 1.4$ & $93.4 \pm 3.2$ & $139.6 \pm 3.5$ & $58.6 \pm 6.4$ & $11.7 \pm 1.2$ & $6.9 \pm 0.7$ \\
III: $2 \%$ Spinach extract & $23.1 \pm 1.4$ & $95.7 \pm 2.9$ & $182.5 \pm 9.0$ & $186.7 \pm 14.8$ & $13.0 \pm 1.4$ & $9.3 \pm 0.6$ \\
IV: 3\% Spinach extract & $26.2 \pm 2.2$ & $97.8 \pm 1.9$ & $172.2 \pm 9.5$ & $199.0 \pm 15.3$ & $16.9 \pm 1.5$ & $9.6 \pm 1.0$ \\
V: $4 \%$ Spinach extract & $27.3 \pm 1.4$ & $106.1 \pm 1.9$ & $170.5 \pm 6.9$ & $212.3 \pm 17.8$ & $18.5 \pm 1.2$ & $11.5 \pm 0.9$ \\
\hline
\end{tabular}

month increased the amount of arsenic to $4.6( \pm 0.4) \mu \mathrm{g} /$ $\mathrm{g}$ tissues (Table II). There was $126.5 \%$ rise in arsenic level, which was statistically significant $(p<0.01)$. Treatment of rat with $1 \%$ hexane extract of spinach for one month decreased the arsenic level to $1.1( \pm 0.3) \mu \mathrm{g} /$ $\mathrm{g}$ tissues, which was $76.6 \%$ less than that of arsenic treated group. This change was statistically highly significant $(\mathrm{p}<0.001)$. Treatment with $2 \%$ hexane extract of spinach for one month decreased the arsenic level to $1.5( \pm 0.3) \mu \mathrm{g} / \mathrm{g}$ tissues, which was $68.6 \%$ less than that of arsenic alone group. This change was also statistically highly significant $(p<0.001)$. Treatment with
$3 \%$ hexane extract of spinach for one month decreased the arsenic level to $1.5( \pm 0.3) \mu \mathrm{g} / \mathrm{g}$ tissues, which was $67.5 \%$ less than that of arsenic treated group. This change was also statistically highly significant $(\mathrm{p}<0.001)$. Treatment with $4 \%$ hexane extract of spinach for one month decreased the arsenic level to $1.4( \pm 0.2)$ $\mu \mathrm{g} / \mathrm{g}$ tissues, which was $69.9 \%$ less than that of arsenic treated group. This change was also statistically highly significant $(\mathrm{p}<0.001)$.

The mean amounts of arsenic in the spleen, kidneys, intestine, lungs and skin of normal healthy rats were 
2.1, 2.7, 2.0, 2.2 and $1.9 \mu \mathrm{g} / \mathrm{g}$ tissues. That is, spleen showed highest amount of arsenic whereas skin had lowest amount of arsenic. Treatment with arsenic for one month increased the tissue levels (spleen- 4.6; kidneys- 6.0 ; intestine- 4.8 ; lungs- 8.2 and skin $4.5 \mu \mathrm{g} / \mathrm{g}$ tissue). Treatment with $1-4 \%$ hexane extract of spinach for one month decreased the arsenic level significantly (Table III).

The concentration of MDA in liver, spleen, kidneys, intestine, lungs and skin were estimated both in the presence or absence of arsenic and hexane extract of spinach. The mean $( \pm$ SE) MDA concentration in the liver of normal healthy rats (Group 0) was $24.3( \pm 2.4)$ $\mathrm{nmol} / \mathrm{L} / \mathrm{mg}$ protein. In rats treated with arsenic (Group I) for one month increased the level of MDA to 40.7 ( \pm 2.0$) \mathrm{nmol} / \mathrm{L} / \mathrm{mg}$ protein (Table IV). There was $67.4 \%$ rise in MDA level; which was statistically highly significant $(\mathrm{p}<0.001)$. Treatment with $1 \%$ hexane extract of spinach for one month decreased the MDA level to 19.3 ( \pm 1.4$) \mathrm{nmol} / \mathrm{L} / \mathrm{mg}$ protein, which was $52.6 \%$ less than that of arsenic control. This change was statistically highly significant $(p<0.001)$.

Treatment with $2 \%$ hexane extract of spinach for one month decreased the MDA level to $23.1( \pm 1.4) \mathrm{nmol} / \mathrm{L} /$ mg protein, which was $43.2 \%$ less. This change was also statistically highly significant $(p<0.001)$. Treatment with $3 \%$ hexane extract of spinach for one month decreased the MDA level to $26.2( \pm 2.2) \mathrm{nmol} / \mathrm{L} / \mathrm{mg}$ protein, which was $35.7 \%$ less than that of arsenic control. This change was statistically highly significant $(p<0.001)$. Treatment with $4 \%$ hexane extract of spinach for one month decreased the MDA level to $27.3( \pm 1.4)$ $\mathrm{nmol} / \mathrm{L} / \mathrm{mg}$ protein, which was $33.0 \%$ less. This change was also statistically highly significant $(p<0.001)$.

More or less similar changes were observed in spleen, kidneys, intestines, lungs and skin (Table IV).

\section{Discussion}

Spinach is a rich source of anti-oxidants and micronutrients, which could be a good solution for management of arsenicosis. After inducing arsenicosis experimentally in rats by feeding them with arsenic trioxide solution through Ryle's tube every alternate day for one month, different concentrations $(1,2,3$ and $4 \%$ ) of $n$-hexane extract of spinach was administered to different groups of rat by the same route every day for one month. At the end of second month the total arsenic level in six vital organs namely- liver, spleen, kidney, intestine, lungs and skin of all the rats were measured by SDDC method by spectrophotometer. The levels were compared with that of arsenic control group. About half the dose of administered arsenic accumulates in the blood of rats, mainly in RBCs. The phagocytic function of reticuloendothelial system of spleen, lungs, liver and other organs serves to engulf and remove these RBCs which are damaged physically and/or immunologically. Therefore, long-term exposure of rats to arsenic cause accumulation of it in RBCs and ultimately in reticuloendothelial system rich in organs like spleen, lungs, liver etc. The data obtained in this study also favors this observation as there was highest accumulation of arsenic in the spleen followed by lung, liver, kidney, skin and lowest accumulation was in intestine. This finding is almost similar to others (Marafante, 1982). Accumulation of arsenic in lungs was also high which is particularly important because one of the principal causes of mortality in arsenicosis is due to lung cancer.

The concentration of arsenic in liver was also high. Disturbances of liver function test were reported in both man and animal after chronic exposure of inorganic arsenic (Guha Mazumder, 2001; Saha et al., 1999).

Accumulation of arsenic in kidney was high also though incidents of renal pathology in chronic arsenic poisoning are less common. The raised level may be due to the process of excretion of arsenic and its metabolites. It was observed that there is a relationship between arsenic exposure in drinking water and bladder cancer in Taiwan, Argentina, Chile, Japan and England.

Besides this, lipid peroxidation in the tissues of all the six corresponding organs was also estimated by MDA method in all the five groups of rat under study.

From previous works it is well documented that micronutrients and anti-oxidants has significant role in the treatment of chronic arsenic poisoning. Selenium (Spallholz et al., 2004), zinc, iron, spirulina (Saha et al., 2005), lipoic acid (Tabassum, 2006), ascorbic acid and atocopherol all has got ameliorating role against chronic arsenic poisoning (Ramanathan et al., 2005; Rabbani et al., 2003). There is metabolic antagonism between arsenic and selenium as arsenite stimulate the excretion of selenium to the bile, so does selenite stimulate the excretion of arsenic (Levander, 1977). In another study, 
selenite was observed to decrease the teratogenic effects of arsenate in pregnant hamsters (WHO, 1981). It was already evident from previous studies that administering arsenic to rats for different periods induces significant increase in arsenic accumulation (Nasir et al., 2002; Kamaludin and Misbahuddin, 2007). In this study emphasis was given on the role of spinach extract to remove arsenic from the tissues. It was also sought to establish a relationship between tissue arsenic level and lipid peroxidation. Arsenic treatment in this experiment resulted a significant increase in lipid peroxidation in all the six tissues of control group. Treatment with different doses of spinach extract in different groups caused significant decrease in lipid peroxidation in all the above tissues, which was dose dependent and occurred more with lower doses. Arsenic content caused extensive oxidation of intramitochondrial NADPH by inhibiting a-ketoacid dehydrogenase (Schiller et al., 1977). NADPH deficiency thus would suppress the reduction of GSSG and ultimately decrease the GSH level. The rise in MDA level was due to the increased release of iron that is believed to be involved in Fenton type of reaction. Arsenic is shown to stimulate the release of iron from ferritin (Ahmad et al., 2000) and through the activation of heme oxygenase (Pi et al., 2002) the rate-limiting enzyme in heme degradation. The free iron is considered as a potent enhancer of ROS formation, as exemplified by the reduction of $\mathrm{H}_{2} \mathrm{O}_{2}$ with the generation of highly reactive hydroxyl radical (Farber, 1994). Depletion of GSH level might result in an alteration in membrane integrity, thereby increasing susceptibility of the membrane to damage following arsenic exposure, leads to production of free radicals and ultimately production of lipid hydroperoxides (Masella et al., 2005).

In the present study, the decreased levels of MDA observed in the spinach extract treated group might be due to the anti-oxidant contents of the spinach extract, which reacted with ROS and/or may lead to regeneration of anti-oxidant pool. These findings are consistent with the results of previous studies (Saha et al., 2005; Tabassum, 2006). It has been observed in previous studies that a-lipoic acid, ascorbic acid and atocopherol showed synergestic activity in decreasing tissue arsenic load when administered simultaneously than individually. a-lipoic acid seems to regenerate ascorbic acid and a-tocopherol from their radical forms. Ascorbate is also having role in decreasing oxidative stress (Xu and Wells, 1996). Ascorbate may decrease the concentration of arsenic in the tissues either by removing the toxic metal from target organ and/or by scavengering ROS directly via $-\mathrm{SH}$ groups. atocopherol does the similar work by inhibiting continuous production of ROS. All the above mechanisms may play a role in concert in decreasing arsenic from different tissues by spinach extract. As spinach is a rich source of vitamins, minerals and micronutrients. All of which possess anti-oxidant properties.

\section{Conclusion}

A combination of vitamins, minerals, anti-oxidants and other micronutrients could be a novel therapeutic measure for the treatment of arsenicosis. However, further studies with spinach extract need to be carried out both in vivo and in vitro to ascertain its therapeutic benefit in chronic arsenic poisoning.

\section{Acknowledgement}

I am grateful to Prof. Mir Misbahuddin of Bangabandhu Sheikh Mujib Medical University, Dhaka, for his kind support and encouragement throughout this work.

\section{References}

Ahmad S, Kitchin KT, Cullen WR. Arsenic species that causes release of iron from ferritin and generation of activated oxygen. Arch Biochem Biophys. 2000; 382: 195-202.

Ahmad SA, Faruquee MH, Sayed MHSU, Khan MH, Jalil MA, Ahmed R, Hadi SA. Chronic arsenicosis: Management by vitamin A, E, C regimen. JOPSOM. 1998; 17: 19-26.

Dey RK. Management protocol for arsenicosis cases: Arsenicosis case-detection, management and surveillance. Report of a regional consultation New Delhi, India, 5-9 Nov, 2002.

Farber JL. Mechanism of cell injury by activated oxygen species. Environ Health Perspect. 1994; 102: 17-24.

Guha Mazumder DN, De BK, Santra A, Ghosh N, Das S, Lahiri $S$, Das T. Randomized placebo-controlled trial of 2,3dimercapto-1-propane-sulfonate (DMPS) in therapy of chronic arsenicosis due to drinking arsenic-contaminated water. J Toxicol Clin Toxicol. 2001; 39: 665-74.

Guha Mazumder DN, Ghoshal UC, Saha J, Santra A, De BK, Chatterjee A, Dutta S, Angle CR, Centeno JA. Randomized 
placebo-controlled trial of 2,3-dimercaptosuccinic acid in therapy of chronic arsenicosis due to drinking arseniccontaminated subsoil water. J Toxicol Clin Toxicol. 1998; 36: $683-90$.

Guha Mazumder DN. Arsenic and liver disease. J Indian Med Assoc. 2001; 99: 311-20.

Hagen TM, Ingersoll RT, Lykkesfeldt J, Liu J, Wehr CM, Vinarsky V, Batholomew JC, Ames BN. (R)-a- lipoic acid supplemented old rats have improved mitochondrial function, decreased oxidative damage and increased metabolic rate. FASEB J. 1999; 13: 411-18.

Kalia K, Flora SJS. Strategies for safe and effective therapeutic measures for chronic arsenic and lead poisoning. J Occup Health. 2005; 47: 1-21.

Kamaluddin M, Misbahuddin M. Zinc supplement reduces tissue arsenic concentration in rats. Bangladesh Med Res Coun Bull. 2006; 32: 87-91.

Khalequzzaman M, Faruque FS, Mitra AK. Assessment of arsenic contamination of groundwater and health problems in Bangladesh. Int J Environ Res Public Health. 2005; 2: 20413.

Kokilavani V, Devi MA, Sivarajan K, Panneerselvam C. Combined efficacies of DL-a-lipoic acid and meso 2,3 dimercaptosuccinic acid against arsenic induced toxicity in anti-oxidant systems of rats. Toxicol Lett. 2005; 160: 1-7.

Levander OA. Metabolic inter-relationship between arsenic and selenium. Environ Health Perspect. 1977; 19: 159-64.

Lowry OH, Rosenbrough NJ, Farr AL, Randall RJ. Protein measurement with the Folin phenol reagent. J Biol Chem. 1951; 193: 265-75.

Marafante E, Bertolero F, Edel J, Pietra R, Sabbioni E. Intracellular interaction and biotransformation of arsenic in rats and rabbits. Sci Total Environ. 1982; 24: 27-39.

Masella R, Di Benedetto R, Vari R, Filesi C, Giovannini C. Novel mechanism of natural anti-oxidant compounds in biological systems: Involvement of glutathione and glutathione related enzymes. J Nutr Biochem. 2005; 16: 57786.

Milton AH, Hasan Z, Shahidullah SM, Sharmin S, Jakariya MD, Rahman M, Dear K, Smith W. Association between nutritional status and arsenicosis due to chronic arsenic exposure in Bangladesh. Int J Environ Health Res. 2004; 14: 99-108.

Misbahuddin M, Islam AZMM, Khandker S, Mahmud IA, Islam N, Anjumanara. Efficacy of spirulina extract plus zinc in patients of chronic arsenic poisoning: A randomized placebo-controlled study. Clinical Toxicol. 2006; 44: 135-41.

Mitra SR, Guha Mazumder DN, Basu A, Block G, Haque R,
Samanta S, Ghosh N, Smith MMH, Ehrenstein OS, Smith AH. Nutritional factors and susceptibility to arsenic-caused skin lesions in West Bengal, India. Environ Health Perspect. 2004; 112: 1104-09.

Nasir M, Misbahuddin M, Ali SMK. Selenium intervention in reducing arsenic levels in different tissues. In: Bangladesh Environment 2002, Proceedings of the 2nd International Conference on Bangladesh Environment. Ahmed MF, Tanveer SA, Badruzzaman ABM (eds). ICBEN-2002, Dhaka, Bangladesh, 2002, pp 343-52.

Pi J, Yamauchi H, Kumagai Y, Sun G, Yoshida T, Aikawa H, Hopenhayn-Rich C, Shimojo N. Evidence for induction of oxidative stress caused by chronic exposure of Chinese residents to arsenic contained in drinking water. Environ Health Perspect. 2002; 110: 331-36.

Piamphongsant T. Management of arsenicosis: Arsenicosis case-detection, management and surveillance. Report of a regional consultation, New Delhi, India, 2002.

Rabbani GH, Saha SK, Akhtar M, Marni F, Mitra AK, Ahmed S, Alauddin M, Bhattacharjee M, Sultana S, Chowdhury AKA. Anti-oxidants in detoxification of arsenic-induced oxidative injury in rabbits: Preliminary results. J Environ Sci Health, Part A: Tox Hazard Subst Environ Eng. 2003; 38: 27387.

Rahman MM, Chowdhury UK, Mukherjee SC, Mondal BK, Paul K, Lodh D, Biswas BK, Chanda CR, Basu GK, Saha KC, Roy S, Das R, Palit SK, Quamruzzaman Q, Chakraborti D. Chronic arsenic toxicity in Bangladesh and West Bengal, India- A review and commentary. J Toxicol Clin Toxicol. 2001; 39: 683-700.

Ramanathan K, Anusuyadevi M, Shila S, Panneerselvam C. Ascorbic acid and a-tocopherol as potent modulators of apoptosis on arsenic-induced toxicity in rats. Toxicol Lett. 2005; 156: 297-306.

Ramos O, Carrizales L, Yanez L, Mejia J, Batres L, Ortiz D, Diaz-Barriga F. Arsenic increased lipid peroxidation in rat tissues by a mechanism independent of glutathione levels. Environ Health Perspect. 1995; 103: 85-88.

Saha SK, Misbahuddin M, Khatun R, Mamun MIR. Effects of hexane extracts of spirulina in the removal of arsenic from isolated liver tissues of rat. Mymensingh Med J. 2005; 14: 191 -95 .

Saha SK, Sikder MS, Zakaria ASM, Ahmed K, Khan MMR, Rahman H, Ray PK, Raihan ASMA, Rahman MT, Hasan M. Chronic arsenic toxicity and liver damage: Report of two cases with review of literature. Bangladesh Med J. 1999; 145.

Schiller CM, Fowler BA, Woods JS. Effects of arsenic on pyruvate dehydrogenase activation. Environ Health Perspect. 1977; 19: 205-07. 
Spallholz JE, Boylan LM, Rahman MM. Environmental hypothesis: Is poor dietary selenium intake an underlying factor for arsenicosis and cancer in Bangladesh and West Bengal, India? Sci Total Environ. 2004; 323: 21-32.

Tabassum NE. Effect of a-lipoic acid on the removal of arsenic from arsenic-loaded isolated liver tissues of rat. Bangladesh J Pharmacol. 2006; 1: 27-32.

WHO. Arsenic. Environmental Health Criteria 18. Geneva,
World Health Organization, 1981.

$\mathrm{Xu}$ DP, Wells WW. A lipoic acid dependent regeneration of ascorbic acid from dehydroascorbic acid in rat liver mitochondria. J Bioenerg Biomembr. 1996; 28: 77-85.

Yoshida T, Yamauchi H, Sun GF. Chronic health effects in people exposed to arsenic via the drinking water: Doseresponse relationship in review. Toxicol Appl Phrmacol. 2004; 198: 243-52. 